Jurnal Tropicrops

Vol 3 No. 2, Agustus 2020: 1-7

ISSN: 2615-7012

\title{
GENETIC DIVERSITY BASED ON GROWTH VARIABLES OF THREE BAMBARA GROUNDNUT LANDRACES (Vigna subterranea (L.) VERDCOURT)
}

\author{
ES. Redjeki, S. Maulidiah, Suhaili, R. Jumadi, R.Agustina, W.Lailiyah, S.Budi. \\ Bambara Groundnut Research Centre (BGRC) \\ Agricultural Faculty, the University of Muhammadiyah Gresik \\ Corresponding author: endah.sriredjeki@umg.ac.id
}

\begin{abstract}
Bambara groundnut has competitive nutritional value such as $49-63.5 \%$ carbohydrate, 15-25\% protein, and $4.5-7.4 \%$ fat. There is not available yet a superior variety. Bambara Groundnut Research Centre has been working intensively to select the candidates of superior variety. Three of bambara groundnut pure lines of BGRC seed collection, including Gresik (Gresik), GHC (Gresik) and S19-3 (Namibia) assessed based on their growth traits, including germination rate, number of leaves, plant height $(\mathrm{cm})$, length of petiole $(\mathrm{cm})$, length of internode (cm), growth type, $1^{\text {st }}$ flowering (das) and $50 \%$ of flowering (das) in the Gresik field $5 \mathrm{~m}$ above sea level, with Random Complete Block Design experiment, three replicates. Analysis of means (ANOM) calculated to test differences between landraces in particular traits. Heritability of three pure lines calculated based on Mean Square Estimated of Analysis of Variance (ANOVA), as well as coefficient correlation, using Minitab 18. The result showed that S19-3 as an introduced landrace from Namibia has traits similarity to the two landraces, namely GHC and Gresik except days to 50\% flowering time. Analysis of means shows that S19-3 has days to 50\% flowering early compare to the others. The trait of 50\% flowering time (dap) also shows a high heritability (0.58). First flowering time has a significant correlation with $50 \%$ flowering time in positive direction.
\end{abstract}

Key words: bambara groundnut, heritability, early flowering, S19-3

\section{INTRODUCTION}

To support food security in Indonesia, BGRC (Bambara Groundnut Research Centre) which belongs to Agricultural Faculty, the University of Muhammadiyah Gresik assess three pure lines of its seed collections, namely Gresik, GHC (Gresik), and S19-3 (from Namibia). The bambara groundnut Indonesia came from Southern Africa (E.S. Redjeki et al., 2020). The crop is famous as completed food with nutritional contains 49-63.5\% carbohydrate, $15-25 \%$ protein, and $4.5-$ $7.4 \%$ fat (Abejide et al., 2018). Even though many advantages of bambara groundnut uses and nutritional contains, this crop is still minor and underutilized legumes. Whereas, Mayes et al. (2019a) concluded that this legume will take an important role to climate change.

Most of bambara groundnut in Indonesia shows low yield, less than 1 ton/ha (Redjeki, 2007). In Africa, Madamba (1995) reported that bambara groundnut produced 4 ton/ha in a suitable environment, and only 0.3 ton/ha in the marginal land. Therefore, this research conducted to find suitable trait for selection among bambara groundnut landraces to prepare a super variety.

\section{METHOD}

This research conducted in the field from July to October 2019. The location is 
Jurnal Tropicrops, Vol 3 No. 2, Agustus 2020: 1-7

5 meter above sea level, with grumusol as soil type. Random Complete Block Design experiment applied for three pure lines, namely Gresik $\left(\mathrm{G}_{1}\right)$, GHC $\left(\mathrm{G}_{2}\right), \mathrm{S} 19-3\left(\mathrm{G}_{3}\right)$ landraces, and repeated three times. There are nine plots with $1 \times 4 \mathrm{~m}^{2}$ square per plot. Planting distance is used $50 \times 25 \mathrm{~cm}$, one plant per hole. Growth variables measure from three days after seed germination until the whole seeds germinated for germination rate observed. Plant height, leaves number, length of petiole and internode, first and $50 \%$ flowering time counted referring to PGRI et al., (2000). Data collected and analyzed by using Minitab 18 software (Minitab, LLC., 2019) for analysis of variance (ANOVA), ANOM (Analysis of Means) and correlation test. Heritability measured based on Mean Square Estimated (Poespodarsono, 1988).

\section{Statistical Analysis}

Data collected from seven variables were analyzed using Minitab 18 package to distinguish three pure lines similarity through Analysis of Means (ANOM). Mean Square Estimated (Table 1) counted from analysis of variance to find genotype variation $\left(\sigma^{2}{ }_{G}\right)$ and phenotype variation $\left(\sigma^{2} \mathrm{P}\right)$. Finally, broad sense heritability $\left(\mathrm{H}^{2}\right)$ calculated based on Allard (1992) formula, it is comparation between genotype variation $\left(\sigma^{2} \mathrm{G}\right)$ and phenotype variation $\left(\sigma^{2} \mathrm{P}\right)$.

Table 1. Mean Square Estimated (Hallauer and Miranda, 1988; Poespodarsono, 1988)

\begin{tabular}{|c|c|c|c|}
\hline Source of Variation & df & Mean Square (MS) & MS estimated \\
\hline $\begin{array}{l}\text { Replicates } \\
\text { Genotype } \\
\text { Error }\end{array}$ & $\begin{array}{c}\mathrm{r}-1 \\
\mathrm{a}-1 \\
(\mathrm{r}-1)(\mathrm{a}-1)\end{array}$ & $\begin{array}{l}\mathrm{MS}_{\mathrm{G}} \\
\mathrm{MS}_{\mathrm{E}}\end{array}$ & $\begin{array}{c}\sigma_{\mathrm{E}}^{2}+\mathrm{r} \sigma_{\mathrm{G}}^{2} \\
\sigma^{2} \mathrm{E}\end{array}$ \\
\hline $\mathrm{r}=$ replicates $; \mathrm{a}=\mathrm{g}$ & $\begin{array}{l}\text { ype numbe } \\
\mathrm{MS}_{\mathrm{E}}=\sigma^{2} \\
\mathrm{MS}_{\mathrm{G}}=\sigma_{\mathrm{E}}^{2} \\
\sigma_{\mathrm{G}}^{2}=(\mathrm{M} \\
\sigma^{2} \mathrm{P}=\sigma^{2} \mathrm{G}\end{array}$ & $\begin{array}{l}\sigma_{\mathrm{G}}=\mathrm{MS}_{\mathrm{E}}+r \sigma^{2} \mathrm{G} \\
\left.-\mathrm{MS}_{\mathrm{E}}\right) / \mathrm{r} \\
\sigma_{\mathrm{E}}^{2}\end{array}$ & \\
\hline
\end{tabular}

\section{Broad Sense Heritability $\left(\mathbf{H}^{2}\right)$}

According to Allard (1992), $\mathrm{H}^{2}=\sigma^{2}{ }_{\mathrm{G}} / \sigma^{2}{ }_{\mathrm{P}}$ $\sigma^{2} \mathrm{P}=$ phenotype variance

$\sigma^{2} \mathrm{G}=$ genotype variance

Furthermore, Stansfield (1991) classify

heritability score as follow:

$0,0<\mathrm{H}^{2}<0,2=$ low

$0,2<\mathrm{H}^{2}<0,5=$ medium

$\mathrm{H}^{2}>0,5 \quad=$ high

\section{Correlation Test}

This analysis was done using Minitab 18 package. 
Redjeki, et al, Genetic Diversity Based ....

\section{RESULT AND DISCUSSION}

Analysis of Means is a complementary curve to Analysis of Variance that investigations the similarity of population means. The graph shows each factor level mean, the overall mean, and the result limits. If a point drops outside the decision limits, then indication exists that the factor level mean characterized by that point is significantly different from the overall mean (Minitab, 2019).
Seven traits assessed from three bambara groundnut pure lines shows that there are no significant differences of six traits, including germination rate, plant height, leaves number, length of internode and petiole as well as days to $1^{\text {st }}$ flowering time (Figure 1a, b, c, d, e, f). That means Gresik, GHC and S19-3 pure lines show similarity to the six traits observed. Furthermore, S19-3 (G) shows days to $50 \%$ flowering time significantly earlier than the others (Figure 1g).

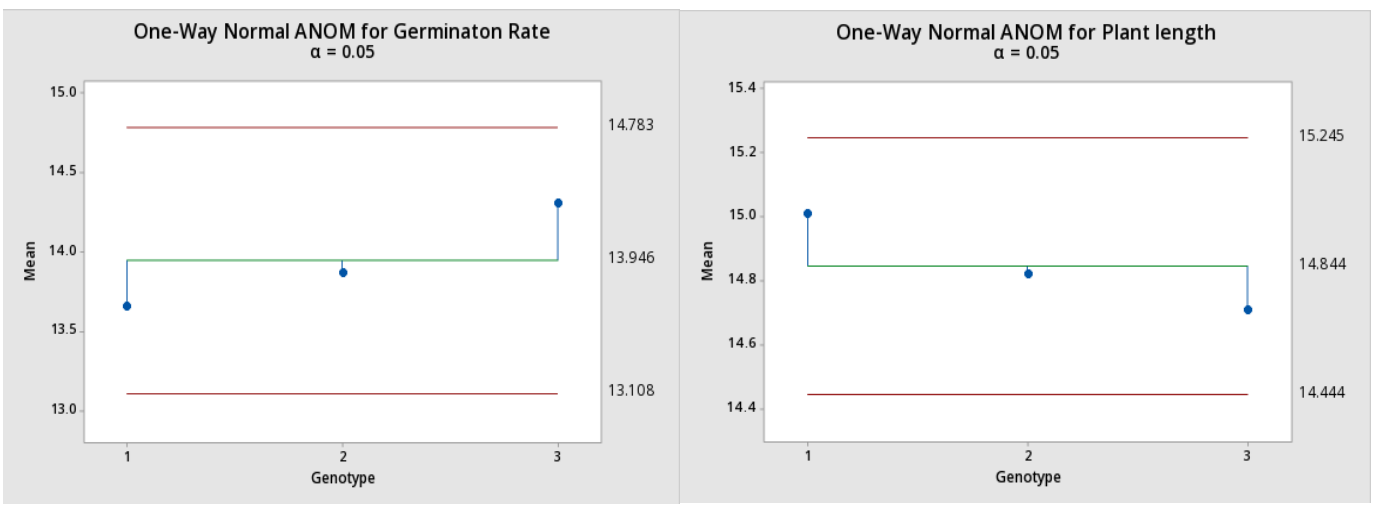

(a)

(b)

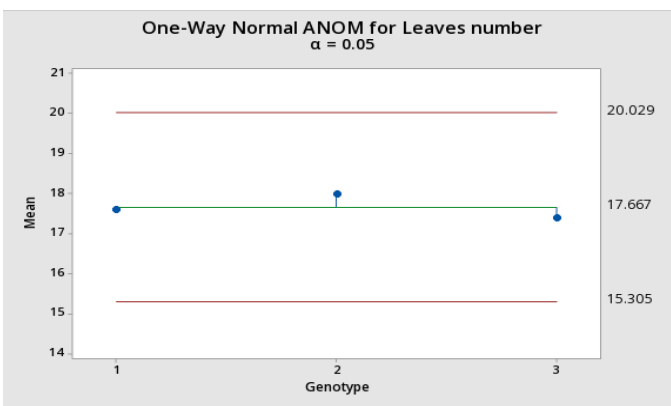

(c)

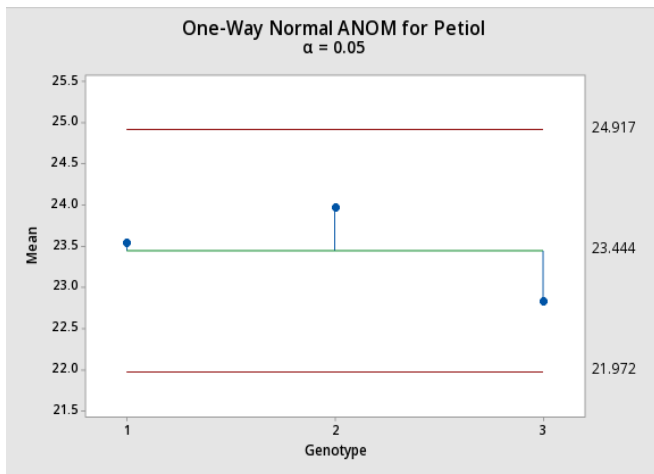

(e)

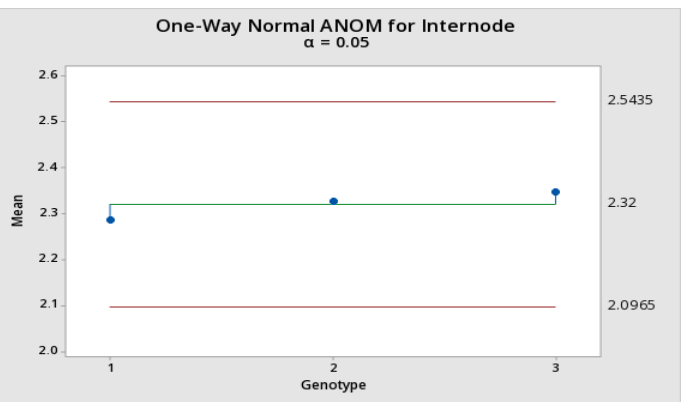

(d)

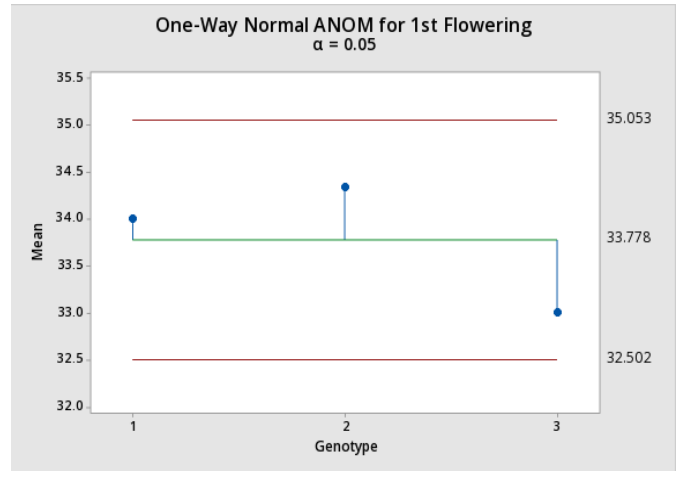

(f) 
Redjeki, et al, Genetic Diversity Based ....

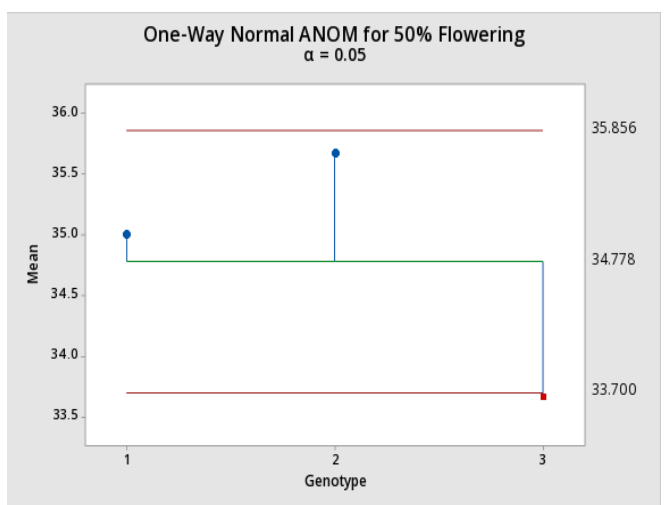

(g)

Figure 1 Analysis of Means (ANOM) (a) germination rates (b) plant height (c) leaves number (d) internode length (e) Petiole length (f) days to $1^{\text {st }}$ Flowering time and (g) days to $50 \%$ flowering time.

S19-3 is an introduced landrace from Namibia in Africa. E.S.Redjeki et al.(2013a) reported that $\mathrm{S} 19-3$ has been well adapted in Indonesia agroekologies. Most of African landraces have early 50\% flowering in Indonesia climate. Previous research conducted in three location for two years in Gresik, Malang and Bojonegoro in East Java showed that S19-3 which has the same colour as Gresik landrace placed in to the three top suitable landraces in Indonesia (E.S. Redjeki, 2013b). This information should be important for breeding program so that S19-3 selected as parent for hibridization to gain a superior variety.

The broad-sense heritability is the ratio of total genetic variance to total phenotypic variance, $\mathrm{H}^{2}=\sigma^{2} \mathrm{G} / \sigma^{2} \mathrm{P}$ (Allard, 1992). Hallauer and Miranda (1988) also
Poespodarsono (1988) reported that heritability can be predicted by Mean Square Estimated (MSE). Table 2 shows Mean Square of Analysis of variance (ANOVA). Whereas, Table 3 placed genotype, environment, and phenotype variance based on MSE (Table 1). Broad sense heritability $\left(\mathrm{H}^{2}\right)$ calculated after all. According to Stansfield (1991) classify heritability score as low $\left(0,0<\mathrm{H}^{2}<0,2\right)$, medium $\left(0,2<\mathrm{H}^{2}<0,5\right)$ and high $\left(\mathrm{H}^{2}>\right.$ $0,5)$. Therefore, only $50 \%$ flowering time shows a high heritability (0.58). That means $50 \%$ flowering time can be used to determine bambara groundnut traits. S19-3 from Namibia belongs to early maturity crops, its harvesting time is 110 days after planting (dap), while Gresik is 150 dap (Mayes, et al., 2019b).

Table 2. Mean Square of ANOVA for growth rate, plant height, leaves number, petiole length, internode length, $1^{\text {st }}$ flowering and $50 \%$ flowering

\begin{tabular}{lccc}
\hline $\begin{array}{l}\text { Source of Variation } \\
\text { /Trait observed }\end{array}$ & Genotipe & Block & Error \\
\hline Degree of Freedom & 2 & 2 & 4 \\
Growth Rate & 0.09 & 0.33 & 0.46 \\
Plant height (cm) & 0.05 & 0.06 & 0.10 \\
Leaves Number & 1.96 & 0.28 & 3.02 \\
Petiole length & 1.17 & 0.98 & 0.97 \\
Internode length & 0.05 & 0.00 & 0.01 \\
$1^{\text {st }}$ Flowering\% & 1.44 & 1.44 & 0.44 \\
$50 \%$ flowering & 3.11 & 0.40 & 0.61 \\
\hline
\end{tabular}


Redjeki, et al, Genetic Diversity Based ....

Table 3. Broad Sense Heritability $\left(\mathbf{H}^{2}\right)$

\begin{tabular}{lcccl}
\hline Traits Observed & $\boldsymbol{\sigma}^{\mathbf{2}}$ & $\boldsymbol{\sigma}^{\mathbf{2}} \mathbf{g}$ & $\boldsymbol{\sigma}^{\mathbf{2}} \mathbf{p}$ & $\mathbf{H}^{\mathbf{2}}=\boldsymbol{\sigma}^{\mathbf{2}} \mathbf{g} \boldsymbol{\sigma}^{\mathbf{2}} \mathbf{p}$ \\
\hline Germination Rate & 0.46 & -0.121 & 0.33 & -0.36 (low) \\
Plant height (8 wap)* & 0.10 & -0.019 & 0.09 & -0.22 (low) \\
leaf number (8 wap) & 3.02 & -0.353 & 2.67 & -0.13 (low) \\
Petiole length (cm) & 0.97 & 0.0687 & 1.04 & 0.07 (low) \\
Internode length (cm) & 0.01 & 0.0115 & 0.02 & 0.48 (moderate) \\
1 $^{\text {st flowering (dap) }}$ & 0.44 & 0.3333 & 0.78 & 0.43 (moderate) \\
50\% flowering (dap)** & 0.61 & 0.8333 & 1.44 & 0.58 (high) \\
\hline
\end{tabular}

*wap = week after planting. $* *$ dap $=$ day after plantig

Heritability score for different characters displayed at Table 2. Among seven quantitave traits, high heritability $(>0.50)$ has been found for days to $50 \%$ flowering (0.58). High heritability at days to $50 \%$ flowering (0.58) means that $58 \%$ of the variability in the trait is due to genetic differences among population. Moderate heritability ( 0.20 to 0.50$)$ has been observed for days to $1^{\text {st }}$ flowering (0.43) and internode length (0.48). Low heritability has been showed for germination rate ($0.38)$, plant height (0.22) and leaf number $(-0.13)$. Moderate to low heritability means that phenotype variance $\left(\boldsymbol{\sigma}^{2} \mathbf{p}\right)$ affected by environment variance $\left(\sigma^{2} \varepsilon\right)$. Therefore, selection activity will be effective when genetic variance $\left(\boldsymbol{\sigma}^{2} \mathbf{g}\right)$ higher than environment variance $\left(\boldsymbol{\sigma}^{2} \boldsymbol{\varepsilon}\right)$. In this research, days to $50 \%$ flowering will be a considered trait for selection.

Correlation coefficient for seven traits display on the Table 4. Significant correlation happens when $\mathrm{P}$-value $<0.05$. Table 4 shows significant correlation in positive direction happen between days to $1^{\text {st }}$ flowering and days to $50 \%$ flowering. It means when days to fist flowering early, days to $50 \%$ flowering early as well.

Table 4. Coefficient correlation seven traits of three pure lines

\section{Pairwise Pearson Correlations}

\begin{tabular}{lllrl} 
Sample 1 & Sample 2 & N Correlation 95\% CI for p P-Value \\
\hline Petiol & Internode & 9 & $0.607(-0.095,0.906)$ & 0.083 \\
Plant length & Internode & 9 & $-0.192(-0.759,0.541)$ & 0.621 \\
Leaves number & Internode & 9 & $0.222(-0.519,0.772)$ & 0.566 \\
Germinaton Rate Internode & 9 & $0.513(-0.230,0.878)$ & 0.158 \\
1st Flowering & Internode & 9 & $0.283(-0.469,0.797)$ & 0.461 \\
50\% Flowering & Internode & 9 & $0.184(-0.547,0.756)$ & 0.635 \\
Plant length & Petiol & 9 & $0.169(-0.558,0.749)$ & 0.664 \\
Leaves number & Petiol & 9 & $0.549(-0.181,0.889)$ & 0.126 \\
Germinaton Rate Petiol & 9 & $-0.071(-0.702,0.623)$ & 0.857 \\
1st Flowering & Petiol & 9 & $0.266(-0.484,0.790)$ & 0.490 \\
50\% Flowering & Petiol & 9 & $0.451(-0.304,0.858)$ & 0.223 \\
Leaves number & Plant length & 9 & $-0.447(-0.857,0.309)$ & 0.228 \\
Germinaton Rate Plant length & 9 & $0.212(-0.526,0.768)$ & 0.583 \\
1st Flowering & Plant length & 9 & $-0.071(-0.702,0.622)$ & 0.856 \\
50\% Flowering & Plant length & 9 & $0.246(-0.500,0.782)$ & 0.523 \\
Germinaton Rate & Leaves number & 9 & $-0.526(-0.882,0.212)$ & 0.145 \\
1st Flowering & Leaves number & 9 & $0.066(-0.626,0.699)$ & 0.867 \\
50\% Flowering & Leaves number & 9 & $0.154(-0.568,0.742)$ & 0.693 \\
1st Flowering & Germinaton Rate & 9 & $0.047(-0.637,0.690)$ & 0.905 \\
50\% Flowering & Germinaton Rate & 9 & $0.010(-0.658,0.670)$ & 0.979 \\
50\% Flowering & 1st Flowering & 9 & $0.772(0.220,0.949)$ & 0.015
\end{tabular}


Redjeki, et al, Genetic Diversity Based ....

Table 5. Growth types, leaf shape, leaf colour and banner flower of Gresik, S19-3 and GHC pure lines

\begin{tabular}{lllll}
\hline Genotipe & Growth Type & $\begin{array}{l}\text { Leaf } \\
\text { shape }\end{array}$ & Leaf colour & Banner flower \\
\hline Gresik $\left(\mathrm{G}_{1}\right)$ & bunch & lancet & green & pigmented \\
$\mathrm{S} 19-3\left(\mathrm{G}_{2}\right)$ & bunch & oval & green & unclear \\
$\mathrm{GHC}\left(\mathrm{G}_{3}\right)$ & bunch & ellipse & green & unclear \\
\hline
\end{tabular}

Referring to descriptor of bambara groundnut (IPGRI et al., 2000), growth type of bambara groundnut is a comparation between petiole and internode length, namely bunch type, if $\mathrm{P} / \mathrm{I}>9$; semi bunch type, if $\mathrm{P} / \mathrm{I}=7-9$; and spreading type (open), if $\mathrm{P} / \mathrm{I}<7$. Table 4 shows that the three pure lines in the same growth type, it is bunch type. Bunch type of bambara groundnut is an ideotype. This type is suitable for large-scale mechanized farming (Karikari, et al., 1997).

\section{CONCLUSION}

Genetic diversity of three pure lines bambara groundnut shows a high heritability at days to $50 \%$ flowering trait. This trait can be effective for selection in breeding program. Days to $50 \%$ flowering corelated significantly to $1^{\text {st }}$ flowering in positive direction.

\section{RECOMMENDATION}

S19-3 (Namibia) has early flowering trait, well adapted in Indonesia agroecology, as well as similar to Gresik landraces in term of phenotype. This S19-3 pure line can be a superior variety candidate. Therefore, depth evaluation is needed for S19-3 before registering to the Ministry of Agriculture in Jakarta, Indonesia.

\section{REFERENCES}

Abejide, Dorcas R, Olamide A. Falusi, Andrew S. Gana, Matthew O. Adebola,Oladipupo A.Y. Daudu, Bolaji Z. Salihu. 2018. Evaluation of Seed Yield of Nigerian Bambara Groundnut (Vigna subterranea (L.) Verdc.) Landraces under Varying Water Conditions. Not Sci Biol, 2018, 10(2):233-239. DOI:

10.25835/nsb10210238

Allard, R.W. 1992. Pemuliaan Tanaman 1.

Terjemahan Manna. Penerbit

Rineka Cipta. Jakarta.

E.S. Redjeki. 2007. Pertumbuhan Dan Hasil Tanaman Kacang Bogor (Vignasubterranea (L.) Verdcourt) Galur Gresik Dan Bogor Pada Berbagai Warna Biji. Prosiding Seminar Nasional Hasil Penelitian Yang Dibiayai Oleh Hibah Kompetitif Bogor, 1-2 Agustus. 114118. ISBN. 978-979-15649-2-2 https://www.academia.edu/2955288/PERTUMBU HAN_DAN_HASIL_TANAMAN_KACAN G_BOGOR_Vigna_subterranea_L._Verdco urt_GALUR_GRESIK_DAN_BOGOR_PA DA_BERBAGAI_WARNA_BIJI

E.S.Redjeki, S Mayes, S Azam-Ali. 2013a. Evaluating the stability and adaptability of bambara groundnut (Vigna subterranea (L.) verd.) landraces in different agroecologiesII International Symposium on Underutilized Plant Species: Crops for the Future-Beyond Food Security 979: 389-400 Acta Hort. 979 ISSN 0567-7572 ISHS 2013 http://www.actahort.org/books/979

E.S. Redjeki, R.Agustina, H. Febriani, S.Azam-ali, Kuswanto, S.Mayes. 2013b.Evaluasi Pertumbuhan Dan 
Redjeki, et al, Genetic Diversity Based ....

Hasil Galur-Galur Kacang Bambara

(Vigna subterranea (L.) Verdcourt) Asal

Indonesia Dan Afrika. Prosiding

Seminar Nasional Fakultas Pertanian

Peternakan UMM.

E.S. Redjeki, Wai Kuan Ho, Niraj Shah, Odireleng O Molosiwa, Noer Rahmi

Ardiarini, Kuswanto Kuswanto, Sean Mayes. 2020. Understanding the genetic relationships of Indonesian bambara groundnut cultivars and investigating their origins. https://www.nrcresearchpress.com/doi /pdf/10.1139/gen-2019-0137

Hallauer, A. R. and J. Miranda. 1988. Quantitative genetics in maize breeding. Ames: Iowa State University Press. Page 33-67

IPGRI, IITA, BAMNET. 2000. Descriptors for bambara groundnut (Vigna subterranea). International Plant Genetic Resources Institute, Rome, Italy; International Institute of Tropical Agriculture, Ibadan, Nigeria; The International Bambara Zimbabwean Condisions. Proceedings of The workshop on Conservation and Improvement of Bambara Groundnut (Vigna subterranea (1.) Verdc.) 14-16 November 1995, Harare, Zimbabwe. 128-134.

Mayes, Sean , Wai Kuan Ho,Hui Hui Chai, Xiuqing Gao,Aloyce C. Kund

Kumbirai I. Mateva, Muhammad Zahrulakmal, Mohd Khairul Izwan, Mohd Hahiree, Presidor Kendabie,Luis C. S. Licea, $\cdot$ F esto Massawe,Tafadzwanashe Mabhau dhi,Albert T. Modi,Joseph N. Berchie, Stephen Amoah,

Ben Faloye,Michael Abberton,Oyatomi Olaniyi, Sayed N. Azam-Ali. 2019a. Bambara groundnut: an exemplar underutilised legume for resilience under climate change. Planta 250, 803-820.
Groundnut Network, Germany. ISBN 92-9043461-9

Karikari, SK; D.J. Wigglesworth, B.C. Kwerepe, T.V. Balole, B. Sebolai and D.C Munthali. 1997. BotswanaCountry Report. In. Heller, J., F. Begemann and J. Mushonga, editors. 1997. Bambara groundnut (Vigna subterranea (L.) Verdc.). Promoting the conservation and use of underutilized and neglected crops. 9. Proceedings of the workshop on Conservation and Improvement of Bambara Groundnut (Vigna subterranea (L.) Verdc.), 14-16 November 1995, Harare, Zimbabwe. Institute of Plant Genetics and Crop Plant Research, Gatersleben/

/Department of Research \& Specialist Services, Harare/International Plant Genetic Resources Institute, Rome, Italy.

Madamba, R. 1995. Breeding Bambara Groundnut Varieties Suitable For

https://doi.org/10.1007/s00425-019$\underline{03191-6}$

Mayes, Sean, Wai Kuan Ho, Hui Hui Chai, Bo Song, Yue Chang and Festo Massawe. 2019b. Bambara groundnut (Vigna subterranea (L.) Verdcourt) A Climate Smart Crop for Food and Nutrition Security. Genomic Designing of Climate Smart Pulse Crops. Chittaranjan Kole (editor). https://doi.org/10.1007/978-3-31996932-9

Minitab, LLC., 2019. ANOVA, ANOM, Correlation. Bruce Pincus, Minitab, LLC 1829 Pine Hall Rd State College, PA 16801

Poespodarsono, S. 1998. Dasar-Dasar Ilmu Pemuliaan Tanaman. Fakultas Pertanian Universitas Brawijaya, Malang. 